\title{
개발도상국의 농업 가치사슬을 확대하기 위한 디지털 기술의 적용
}

목 차

I. 서 론

II. 개발도상국의 농업 가치사슬 확대와 디지털 기술 적용

1. 지속가능개발목표(SDGs) 달성을 위한 농업 분야 가치사슬 확대의 필요성

2. 농업 가치사슬을 확대하기 위한 디지털 기술 적용의 의미와 목표

III . 미국국제개발처(USAID)의 디지털 농업 사업 전략 및 추진 사례

1. USAID의 Feed the Future 디지털 개발 프로그램

2. USAID의 모바일 농업 민관 파트너십 사업 사례

IV. 결론 및 시사점

1. 농업 가치사슬을 확대하기 위한 디지털 기술의 적용

2. KOICA의 사업 사례와 향후 적용을 위한 시사점

참고 문헌 


\section{요 약}

17 개의 지속가능개발목표(Sustainable Development Goals, SDGs) 중 2번 목표는 “기아의 종식, 식량 안보, 영양 개선 및 지속 가능 농업의 달성”이다. 2050년 98억 명에 이를 것으로 전망되는 세계 인구를 위한 식량 공급은 여전히 인류가 해결해야 할 난제다. 그러나 전 세계 도시화와 기후변화로 인해 생산 가능한 토지 면적과 농촌 지역의 노동 인력은 줄어들고 있는 상황에서, 한정된 자원의 한계를 극복하기 위한 생산성 증대의 농업기술 혁신이 필요한 상황이다.

최근 4차 산업혁명에서 강조되는 디지털 기술은 농업 분야에도 중요하게 적용되고 있다. 개발도상국은 선진국의 기술 발전 단계를 건너뛰는 기술의 보급을 통해 낙후된 농업의 가치사슬을 확대하는 노력을 하고 있으며, 이 과정에서 주로 다루어지는 것이 모바일을 활용한 기술이다. 모바일을 통한 결제 및 대출 등의 금융 서비스 접근성 향상, 농업기술을 지도하고 역량을 강화하기 위한 농업기술 정보제공 서비스, 물류-유통의 공급사슬 관리, 시장 접근성을 개선하기 위한 무역·입찰·거래 플랫폼 서비스 제공 등의 방식으로 모바일 기술을 활용할 수 있다.

본고에서는 농업 분야 개발협력 사업에 디지털(모바일) 기술의 적용 목표와 그 의미를 파악하고, 실제 사업 사례를 살펴보고자 한다. 공여기관(USAID)과 통신업체(Vodafone), 현지 NGO(TechnoServe)가 협력해 케냐, 탄자니아, 모잠비크에서 수행한 모바일 농업 사업의 사례를 검토하고, 이를 바탕으로 향후 우리나라의 농업 분야 사업에 적용 가능한 시사점을 도출하고자 한다. 


\section{I. 서론}

2018년 국제연합식량농업기구(Food and Agriculture Organization of the United Nations, 이하 FAO)의 발표에 따르면, 2050년경 전 세계 인구는 약 98억 명까지 증가해 식량 소비가 현재보다 $70 \%$ 가량 증대될 것이라고 한다. 현재 기후변화로 인한 기상이변 현상으로 세계 식량 공급은 여전히 불안한 상황이며, 도시화로 인해 농지 면적과 농촌 지역 노동 인력은 점점 줄어들고 있다. 이러한 상황을 극복하기 위한 국제사회의 노력은 새천년개 발목표(Millennium Development Goals, MDGs)에 이어 지속가능개발목표(Sustainable Development Goals, 이하 SDGs)에도 여전히 주요한 목표로 설정되어 이행되고 있다.

농업은 기아와 빈곤 극복(SDGs 1)을 위해 자원(SDGs $6,13,14,15)$ 을 이용해 식량을 생산(SDGs 2)하며, 이 과정에서 경제적 - 사회적 발전(SDGs $3,4,5,7,8,12,17$ )에 기여한다. $\mathrm{SDGs}$ 의 거의 모든 목표에 걸쳐 연관되어 있는 농업 분야 $(<$ 표 $1>)$ 는 개발도상국의 경제 발전 에 있어 중요한 역할을 차지하는 산업으로, 1 차 산업의 개념에서 나아가 최근 들어 화두가 되고 있는 4 차 산업혁명의 영역에서도 여전히 중요한 분야로 인식되고 있다.

세계경제포럼(World Economic Forum, 이하 WEF)이 최근 수년간 주요한 이슈로 이끌고 있는 4차 산업혁명은 11 대 과제와 14 개 시스템 이니셔티브1)를 통해 추진되고 있다. 이중 농업 분야에서는 「식량안보 및 농업의 미래 이니셔티브」를 통해 '목적을 위한 혁신(Innovation with a Purpose)' 프로젝트가 수행되고 있다. 식량 시스템의 근원적인 전환을 목표로 하는 동 프로젝트의 1 단계에서는 정책, 투자, 기업가 정신 등에 있어 실현 가능한 수준의 혁신 기술이 무엇인지 검토한다. 또 2 단계에서는 글로벌 수준의 투자자, 혁신가, 정책 입안자, 농민 등 모든 이해관계자가 연계되는 파트너십을 구성해 혁신을 가속화하는 방식으로 추진되고 있다.

1) 세계경제포럼(World Economic Forum)의 11대 추진 과제로는 $\triangle$ 신기술에 대한 규제, $\triangle$ 성차별 해소 $\triangle$ 경제성장 측정의 재정의, $\triangle 4$ 차 산업혁명을 위한 기술 역량 강화, $\triangle$ 기후변화 도전과제 충족, $\triangle$ 미래를 위한 계획, $\triangle$ 무역의 장점 확대, $\Delta$ 수입과 지출의 균형, $\triangle 4$ 차 산업혁명의 거버넌스 확립, $\Delta$ 생산성 위기 극복, $\Delta$ 사이버 보안 강화 등이 있다. 이를 이행하기 위한 14 개의 이니셔티브로는 $\triangle$ 소비의 미래, $\triangle$ 디지털 경제 및 사회 미래, $\triangle$ 경제성장과 사회 통합의 미래, $\triangle$ 교육·성역할·직장의 미래, $\triangle$ 에너지의 미래, $\Delta$ 환경 및 천연자원 안보의 미래, $\triangle$ 금융 및 통화 시스템의 미래, $\triangle$ 식량안보와 농업의 미래, $\triangle$ 건강과 보건의 미래, $\triangle$ 정보와 엔터테인먼트의 미래, $\triangle$ 국제무역 과 투자의 미래 등이 추진 중에 있다(이효정, 2018 참조). 
〈표 1〉 지속가능개발목표(SDGs)와 농업 · 식량 시스템의 연관 관계

\begin{tabular}{|c|c|}
\hline $\begin{array}{l}\text { SDGs } \\
\text { 목표 }\end{array}$ & 농업과 식량 시스템의 연관 내용 \\
\hline 1 & 전 세계 빈곤 인구의 $80 \%$ 가 농촌 지역에 거주하며 농업에 종사하고 있음 \\
\hline 2 & 전 세계적으로 충분한 식량이 공급되고 있지만, 여전히 8억 명은 만성적인 영양결핍 상태임 \\
\hline 3 & $\begin{array}{l}\text { 영양 불량은 전 세계에서 발생하는 질병의 가장 큰 원인 중 하나이며, } 40 \text { 억 명은 미량원소 결핍 } \\
\text { 또는 과체중을 겪고 있음 }\end{array}$ \\
\hline 4 & 영양 불량은 5 세 미만 아동의 $1 / 4$ 정도에서 학업성취도, 두뇌 발달에 영향을 줌 \\
\hline 5 & $\begin{array}{l}\text { 여성은 농업 생산 활동의 } 43 \% \text { 를 차지함에도 불구하고 토지, 기술, 시장 등의 자원 접근성에 있어 } \\
\text { 차별받고 있음 }\end{array}$ \\
\hline 6 & 식량 시스템은 전 세계 담수의 $70 \%$ 를 이용하고 있음 \\
\hline 7 & 현대화된 식량 시스템은 전 세계 에너지의 $30 \%$ 를 소비하고 있으며, 대부분 화석연료에 의존함 \\
\hline 8 & 농업은 전 세계 고용의 가장 많은 부분을 차지하며, 이중 $60 \%$ 가 개발도상국의 노동자임 \\
\hline 9 & 9억 명에 이르는 농촌 지역 주민은 농업에 종사하고 있으나 전기 접근성 없음 \\
\hline 10 & 지난 30년간 10 명 중 7 명이 건강한 식품에 대한 접근 불평등을 겪음 \\
\hline 11 & $\begin{array}{l}\text { 2030년까지 전 세계 인구의 } 60 \% \text { 가 도시 지역에 거주할 것으로 예상되며 또 소비시장의 변화, } \\
\text { 토지와 자원의 이용에 대한 부담 증대 }\end{array}$ \\
\hline 12 & 전 세계 생산량의 약 $1 / 3$ 에 해당하는 13 억 톤의 식량이 낭비되거나 손실되고 있음 \\
\hline 13 & $\begin{array}{l}\text { 식량 시스템은 전 세계 온실가스 배출량의 } 20 ~ 30 \% \text { 를 차지하며, 기후변화로 인해 작물 생산성이 } \\
25 \% \text { 이상 감소됨 }\end{array}$ \\
\hline 14 & 어류는 동물성 단백질 섭취의 $17 \%$ 를 차지하나, 이중 $30 \%$ 가 남획된 자원임 \\
\hline 15 & 농업은 산림녹화에서 가장 중요한 요소로, 2016년 기준 3천만ha 이상으로 녹화가 진행 중임 \\
\hline 16 & 8억 1천5백만 명은 영양 부족 상태로, 식량 불안정은 분쟁의 원인이자 결과가 되고 있음 \\
\hline 17 & $\begin{array}{l}\text { 파트너십은 식량 시스템 전환의 결정적인 요소인데, 2030년까지 민간 부문에서 매년 2조 3천억 } \\
\text { 달러가 투자될 계획임 }\end{array}$ \\
\hline
\end{tabular}

출처: WEF (2018); 이효정 (2018)에서 재인용

이 프로그램은 농업 부문에 적용할 수 있는 혁신적인 도전 과제를 첫째, 수요 형태의 변화(Changing the shape of demand), 둘째, 가치사슬 연계 확장(Promoting value chain linkages), 셋째, 효율적 생산 시스템의 창조(Creating effective production systems)로 구분하고 있다. 특히, 본고에서 논의하고자 하는 가치사슬과 관련한 기술 적용 분야는 모바일 서비스, 빅데이터 및 보험 분석 기술, 사물인터넷을 통한 실시간 공급이력관리, 블록체인을 통한 이력 추적 등이 있다.

본고에서는 농업 분야 공적개발원조(Official Development Assistance, 이하 ODA) 사업 에서 개발도상국의 농업 생산성을 높이고, 가치사슬을 확대해 지속 가능한 소농의 소득 증대를 위해 디지털 기술을 사업에 적용시키기 위한 방안을 모색해 보고자 한다. 이를 위해 선진 공여기 관의 농업 분야 디지털화 전략과 사업 사례를 검토하고, 향후 우리나라 $\mathrm{ODA}$ 부문에 적용 가능한 접점을 도출해 내는 데 활용한다. 


\section{II. 개발도상국의 농업 가치사슬 확대와 디지털 기술 적용}

\section{1. 지속가능개발목표(SDGs) 달성을 위한 농업 분야 가치시슬 확대의 필요성}

개발도상국에서는 국가 국내총생산(Gross Domestic Product, 이하 GDP) 중 10 35\% 가량을 농업 부문이 차지한다(GSMA, 2017). 특히, 사하라 이남 아프리카의 식음료 산업(농업 포함)은 2010년 3,130억에서 2030년에는 1조 달러에 이를 것으로 예상되고 있다(Africa Growth Initiative, 2018).

농업 분야에서 가치사슬(value chain)2)이란 농산물이 생산되어, 원재료 상태로 유통 과정을 거쳐 최종 소비에 이르기까지 참여한 다양한 이해관계자들이 시행한 모든 활동을 의미한다. 여기서 활동은 농산물 이외에도 농산물의 저장 - 유통 - 판매 과정에 투입된 서비스와 자원, 정보의 모든 흐름을 의미한다(FAO, 2013; IFAD, 2016). 가치사슬에서 말하는 주요 활동은 농산물의 공급사슬을 의미하는 것으로, <그림 $1>$ 에서 핵심 가치사슬의 단계, 즉 '투입재 생산 - 집하-저장 - 가공-유통'의 과정을 의미한다. 농산물 가치사슬에서 공급사슬이라는 용어 대신에 가치사슬을 사용한 것은, 농산물이 공급사슬의 단계를 따라 이동할 때 추가적으로 가치 가 발생하기 때문이다.

\section{〈그림 1〉 농업 가치시슬 구조도}

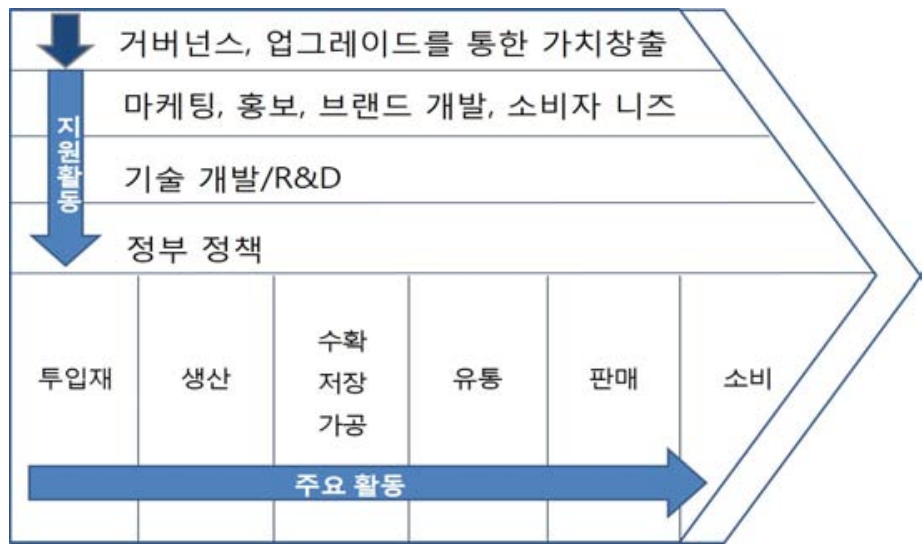

출처: 김수진 · 이효정 · 오수현 (2016)에서 재인용

2) 기업의 활동을 통해 부가가치(added value)를 생성하는 연쇄 과정을 일컫는 말로, 부가가치 창출에 직간접적으로 영향을 미치는 모든 활동(activity) 및 기능(function), 프로세스 간의 연결 형태(linkages)라고 정의할 수 있다 (Porter, 1985: 김수진 외 (2016)에서 재인용). 
국가 간 교역이 증대하고 또 새로운 시장 개척을 위한 다국적 농식품 기업의 활동이 개발도상 국에서 선진국까지 확장됨에 따라, 농업 분야의 개발협력 사업에서도 가장 중요한 화두 중 하나가 가치사슬에 있다고 해도 과언이 아니다(UNIDO, 2011; IFAD, 2014). 이 과정에서 사업의 수혜 대상으로만 여겨졌던 개발도상국의 농민을 경제활동의 주체로 인식하고, 이들이 가치사슬의 생산 단계에만 개입하던 단계에서 벗어나 모든 단계의 주요 이해관계자로서 역할을 재정립하고 있는 상황이다.

특히, SDGs에서 목표로 하는 빈곤 감소, 고용 창출, 소득 증대, 경제성장, 기업 발전, 환경 친화적 생산 및 지속 가능성 등 다양한 측면에서 가치사슬과 상관관계를 분석한 연구 결과에 따르면, 거의 모든 항목에서 긍정적인 상관관계가 있다는 것을 알 수 있다. 특히 빈곤 감소와 경제성장 등 민간 기업의 발전에 긍정적인 영향을 미치는 것으로 나타났다(UNIDO, 2011). 하지만, 김동훈 외(2016)의 연구에 의하면, 전체 연구 중 우리나라 농업 분야 국제개발협력 연구에서 가치사슬의 비중은 높지 않은데, 이는 농업에서의 경제적 행위에 대한 연구자들의 관심이 높지 않기 때문이라고 진단했다. 국가별·농업기술별·특정 작물별 국제개발협력의 상황 에 주로 초점이 맞추어져 있는 상황이다. 김연중 외(2010)의 연구에서도 가치사슬을 주제로 하는 연구는 기업경영, IT, 문화 및 디지털 콘텐츠, 제조업 등 비농업 분야에서 주로 수행되고 있으며, 농업 분야에서는 공급사슬 관점에서의 연구가 주를 이룬다고 했다.

최근 개발협력 분야에서 농업의 가치사슬에 대한 고려 추세는 전 세계적인 농식품 시장의 구조적인 변화를 반영한 흐름이라고 할 수 있다. 인도, 중국 등의 인구 증가와 식생활 서구화, 기후변화로 인한 생태계 변화, 국가 간의 교역 증진 등의 사회·경제·환경적인 변화는 글로벌 농업 및 식품시장의 변화를 가져왔고, 이로 인해 세계경제에도 영향을 미치고 있다(이효정, 지성태, 2016). 이렇듯, 변화하는 글로벌 환경에 적응하고, 민간 부문의 참여를 통한 개발 재원의 확보, 개발도상국의 지속 가능한 경제 발전을 위해 가치사슬의 확대 발전이 필요한 시점이다.

\section{2. 농업 가치시슬을 확대하기 위한 디지털 기술 적용의 의미와 목표}

농업 부문의 혁신은 2050 년경 약 100 억 명에 달할 것으로 예상되는 인류를 위한, 식량 공급을 목표로 하는 식량 시스템 전환의 기초가 된다. 농업 분야에서 기술은 식량을 생산하는 데 필요한 투입재(종자, 비료, 기계)를 비롯해 재배-수확-저장-유통의 가치사슬 단계에서 필요한 다양한 기술을 의미한다. 이러한 기술의 발전과 혁신을 통해 미래의 변화에 대응할 수 있으며, 소위 ‘4차 산업혁명'에서 언급되는 여러 가지 첨단기술 분야는 이런 의미에서 농업에서도 적용되고 있기도 하다. 
농업은 개발도상국의 $\mathrm{GDP}$ 에서 10 35\% 가량을 차지하고 있으며, 국가 경제의 발전에 중요 한 산업 분야다(World Bank, 2017). 인구가 증가함에 따라 세계 식량의 수요가 꾸준히 증가하 고 있으며, 도시화로 인해 생산 가능한 토지 면적이 점점 줄어들고 있다. 이런 상황에서 단위면 적당 생산성을 높이고 또 수확 후 손실되는 양을 줄임으로써 보급되는 식량의 양을 늘리고자 하는 것이 SDGs에서 달성하고자 하는 목표인 것이다(각각 SDGs 2번과 12번 목표).3)

본고에서는 이러한 목표 달성을 위한 전환과 혁신의 해결 방안으로, 디지털 기술을 적용하는 방법을 고찰하고자 한다. $\mathrm{FAO}(2013)$ 는 기술정보 접근성, 시장 접근성, 금융 접근성 제고의 관점에서 디지털 기술이 농업 생산성을 향상시킨다고 했다. OXFAM 외(2011)는 농산물의 공급사슬 단계별로 모바일 활용이 가능한 요소를 설정하고, <표 2>와 같이 네 가지 목표로 구분해 제시하고 있다. 모바일을 통한 결제, 대출 등 금융 서비스의 접근성 향상, 농업기술을 지도하고 역량을 강화하기 위한 농업기술 정보제공 서비스, 물류-유통의 공급사슬 관리, 시장 접근성을 개선하기 위한 무역 - 입찰 - 거래 플랫폼 구성을 목표로 모바일 기술의 활용이 가능하 다(이효정, 2014.a). 이때 각 목표를 달성하기 위한 솔루션과 지원 내용, 분석을 위한 기초 데이터의 종류 등이 제시되고 있다. 이는 향후에 신규 사업의 발굴 시 해당 사항이 사업의 목표로 정해지면 기초자료조사를 통해 해당 솔루션이 사업 요소로 타당한지 검토하는 데 참고가 될 수 있다.

〈표 2〉 모바일 기술을 활용한 농업 부문의 활용 기회와 주요 분석지표

\begin{tabular}{|c|c|c|c|c|}
\hline 목표 & 활동 내용 & 모바일 솔루션 & 기술 지원 내용 & 주요 분석 지표 \\
\hline \multirow{3}{*}{$\begin{array}{l}\text { 금융서 } \\
\text { 비스 } \\
\text { 접근성 } \\
\text { 향상 }\end{array}$} & \multirow{3}{*}{$\begin{array}{c}\text { 농업 활동 } \\
\text { 단계별 } \\
\text { 맞춤형 금융 } \\
\text { 서비스 제공 }\end{array}$} & $\begin{array}{l}\text { 모바일 결제 } \\
\text { 시스템 }\end{array}$ & $\begin{array}{l}\text { 등록된 이용자들을 대상으로 하 } \\
\text { 는 결제 시스템 도입 }\end{array}$ & $\begin{array}{l}\text { 농업 분야 고용 인구수, 모바일 보 } \\
\text { 급률, 월간 거래 건수, 도시 간 평균 } \\
\text { 거리 }\end{array}$ \\
\hline & & $\begin{array}{l}\text { 소액보험 } \\
\text { 시스템 }\end{array}$ & $\begin{array}{l}\text { 투입재 구매 시 보험 서비스를 추 } \\
\text { 가로 가입하기 위한 재원 지급 }\end{array}$ & $\begin{array}{l}\text { 곡물을 생산하기 위한 토지 면적, } \\
\text { 시비량, 종자 투입량, 비료 - 종자 } \\
\text { 가격 }\end{array}$ \\
\hline & & $\begin{array}{l}\text { 소액대출 } \\
\text { 플랫폼 }\end{array}$ & $\begin{array}{l}\mathrm{P} 2 \mathrm{P} \text { 거래 또는 외부 투자자들에 } \\
\text { 대한 광고를 통해 제공 }\end{array}$ & $\begin{array}{l}\text { 농민 수(2ha 미만 소농 기준), 모바 } \\
\text { 일 보급률, ha당 투입재 비용 }\end{array}$ \\
\hline \multirow{2}{*}{$\begin{array}{l}\text { 농업기 } \\
\text { 술 정보 } \\
\text { 제공 }\end{array}$} & \multirow{2}{*}{$\begin{array}{c}\text { 재배 기술, } \\
\text { 상품 가격, } \\
\text { 기상예보 } \\
\text { 등의 정보 } \\
\text { 제공 }\end{array}$} & $\begin{array}{l}\text { 모바일 정보 } \\
\text { 플랫폼 }\end{array}$ & $\begin{array}{l}\text { 매주 정보 제공(푸쉬 메시지 혹은 } \\
\text { 수요 기반 정보) }\end{array}$ & $\begin{array}{l}\text { 농민 수(2ha 미만 소농 기준), 모바 } \\
\text { 일 보급률, 월별 구독률 }\end{array}$ \\
\hline & & $\begin{array}{l}\text { 농민 대상 } \\
\text { 헬프데스크 }\end{array}$ & $\begin{array}{l}\text { 농업기술 전문가에 의한 수요 기 } \\
\text { 반 정보 제공(음성 제공) }\end{array}$ & $\begin{array}{l}\text { 농민 수(2ha 미만 소농 기준), 모바 } \\
\text { 일 보급률, 월별 통화율 }\end{array}$ \\
\hline
\end{tabular}

3) (SDG 2.4) 2030년까지 생산(성) 증대, 생태계 유지, 기후변화 적응 역량을 강화해 지속가능식량생산 시스템 보장 /(SDG 12.3) 2030년까지 소매, 개인 차원에서 식품 낭비 반감, 수확 후 손실을 포함해 생산과 공급사슬에서 발생하는 식품 손실 경감(저자 주). 


\begin{tabular}{|c|c|c|c|c|}
\hline 목표 & 활동 내용 & 모바일 솔루션 & 기술 지원 내용 & 주요 분석 지표 \\
\hline \multirow{4}{*}{$\begin{array}{l}\text { 공급사 } \\
\text { 슬 관리 }\end{array}$} & \multirow{4}{*}{$\begin{array}{l}\text { 공급망 관리 } \\
\text { 최적화, 물류, } \\
\text { 배송 효율성 } \\
\text { 향상 }\end{array}$} & $\begin{array}{l}\text { 스마트 물류 } \\
\text { 시스템 }\end{array}$ & $\begin{array}{l}\text { 배송 차량 이동에 대한 모바일 기 } \\
\text { 반의 추적 디바이스 }\end{array}$ & 농산물 총 수출입량, 도로 이용률 \\
\hline & & $\begin{array}{l}\text { 위치추적 } \\
\text { 시스템 }\end{array}$ & 식량 공급 단계별 상품 배송 기록 & $\begin{array}{l}\text { 농민 수(2ha 미만 소농 기준), 수출 } \\
\text { 업자당 모니터링 에이전트 숫자 }\end{array}$ \\
\hline & & $\begin{array}{l}\text { 공급자 } \\
\text { 네트워크 } \\
\text { 모바일 관리 }\end{array}$ & $\begin{array}{l}\text { 생산자 네트워크 관리를 위해 구 } \\
\text { 매자에게 모바일 기술 제공 }\end{array}$ & $\begin{array}{l}\text { 농민 수(2ha 미만 소농 기준), 수출 } \\
\text { 업자와 협력하는 농장 에이전시 숫 } \\
\text { 자 }\end{array}$ \\
\hline & & $\begin{array}{l}\text { 유통 네트워크 } \\
\text { 모바일 관리 }\end{array}$ & $\begin{array}{l}\text { 상품 목록, 농촌 지역 유통 네트 } \\
\text { 워크를 관리하기 위해 투입재 공 } \\
\text { 급사들에게 모바일 기술 제공 }\end{array}$ & $\begin{array}{l}\text { 농민 수(2ha 미만 소농 기준), 농민 } \\
\text { 당 유통업자 수, 모바일 디바이스 } \\
\text { 개수 }\end{array}$ \\
\hline \multirow{3}{*}{$\begin{array}{l}\text { 시장 } \\
\text { 접근성 } \\
\text { 향상 }\end{array}$} & \multirow{3}{*}{$\begin{array}{l}\text { 무역상, } \\
\text { 구매자, } \\
\text { 판매자 간 } \\
\text { 연계 강화 }\end{array}$} & $\begin{array}{l}\text { 농업 무역 } \\
\text { 플랫폼 }\end{array}$ & \multirow{3}{*}{$\begin{array}{l}\text { 서비스 및 상품 판매 등을 목적으 } \\
\text { 로 농민, 무역상 등에 모바일(인 } \\
\text { 터넷) 포털을 이용해 정보 제공 }\end{array}$} & $\begin{array}{l}\text { 농민 수(2ha 미만 소농 기준), 모바 } \\
\text { 일 보급률, 월별 거래 건수 }\end{array}$ \\
\hline & & $\begin{array}{l}\text { 농업 입찰 } \\
\text { 플랫폼 }\end{array}$ & & $\begin{array}{l}\text { 농민 수(2ha 미만 소농 기준), 모바 } \\
\text { 일 보급률, 도시 간 평균 거리 }\end{array}$ \\
\hline & & $\begin{array}{l}\text { 농업 거래 } \\
\text { 플랫폼 }\end{array}$ & & $\begin{array}{l}\text { 농민 수(2ha 미만 소농 기준), 모바 } \\
\text { 일 보급률, 도시 간 평균 거리 }\end{array}$ \\
\hline
\end{tabular}

출처: OXFAM, Vodafone, and Accenture (2011) 


\section{III. 미국국제개발처(USAID)의 디지털 농업 사업 전략 및 추진 사례}

\section{USAID의 Feed the Future4) 디지털 개발 프로그램}

미국국제개발처(United States Agency for International Development, 이하 USAID) 는 '디지털개발원칙(Principles for Digital Development)'5)을 수립하고, 디지털 기술의 통합 적 적용을 위해 노력하고 있다. 동 원칙에 따른 '디지털개발전략(Digital Development Strategy)'에서는 $\boldsymbol{\Delta}$ 디지털 포용(Digital Inclusion), $\boldsymbol{\Delta}$ 디지털 금융(Digital Finance),

개발정보학(Digital Information), $\boldsymbol{\Delta}$ 지리공간센터(The GeoCenter), $\boldsymbol{\Delta}$ FTF를 위한 디지 털 개발(Digital Development for Feed the Future, D2FTF)을 주요 전략으로 설정하고 사업을 추진 중에 있다.

USAID의 농업 분야 지원 이니셔티브인 Feed the Future에서는 Global Development $\mathrm{Lab}(\mathrm{Lab})^{6)}$, 미국 식량안보국(the Bureau for Food Security)과 함께 디지털 개발 프로그램 인 "Digital Development for Feed the Future"(D2FTF)를 수행 중에 있다. D2FTF는 Feed the Future를 통해 통합적으로 지원되는 디지털 전략 이행 도구로서 $\mathrm{FtF}$ 프로그램의 기술적 지원, $\mathrm{FtF}$ 팀의 역량 강화, 우수 사례 경험을 공유해 역량 강화 등의 방법으로 지원·추진 되고 있다. 디지털 기술 유형에 따라 정밀 농업, 디지털 금융 서비스 농업지도, 데이터 중심의 농업, 디지털 농업지도 등 네 영역으로 나누어 추진되고 있다.

1) 정밀농업(Precision agriculture including sensor technology)

정밀농업은 미국과 같은 선진국에서는 고부가가치 작물을 재배할 때 정밀 센서를 이용해 작물의 물 흡수량이나 작기를 정확하게 측정 - 모니터링해 자동화하는 방식을 주로 의미한다.

4) Feed the Future: USAID의 농업 부문 이니셔티브로서 식량 안보와 영양 개선을 목표로 하며, 자세한 사항은 이효정 (2014b) 참조.

5) USAID의 9가지 '디지털 원칙'은 다음과 같음(USAID, 2018) : (1) 사용자와 함께 설계할 것(Design with user) (2) 현 생태계를 이해할 것(Understand the Existing Ecosystem) (3) 실제 사업으로 이어질 수 있게 설계할 것 (Design for Scale) (4) 지속 가능성을 고려할 것(Build for Sustainability) (5) 데이터를 기반으로 할 것(Be Data Driven) (6) 누구나 접근 가능한 데이터를 이용할 것(Use Open Data, Open Standard, Open Source, Open Innovation) (7) 재사용하고 향상시킬 것(Reuse and Improve) (8) 사생활 및 보안에 신경 쓸 것(Address Privacy and Security) (9) 협력할 것(Be Collaborative)

6) USAID가 운영하는 Global Development Lab의 디지털 기술 및 데이터 전담 조직인 '디지털개발센터(Center for Digital Development)'는 개발도상국에서 모바일 및 디지털 기술의 접근성을 개선하는 방안을 연구하고 새로운 기술을 적용하는 데 필요한 논의를 주도하는 조직임(이상급, 2018). 
개발도상국에서는 상대적으로 저렴한 센서를 이용해 토양을 분석하고, 투입재에 대한 예측 및 기상정보 모니터링 등과 같은 가치사슬 전반에 걸쳐 적용되고 있다.

\section{2) 디지털 금융 서비스(Digital financial services)}

디지털 금융은 디지털 채널(모바일, 컴퓨터, 태블릿 등)을 통한 저축, 신용 및 보험 접근성, 거래 활동 촉진 등을 목표로 한다. 또한 농업의 가치사슬에서 만성적인 문제점으로 지적되는 사항, 특히 농촌 지역의 시장 접근성 향상을 도모한다.

3) 데이터 중심의 농업(Data-driven agriculture)

$\mathrm{FtF}$ 는 지역 단위에서 데이터와 정보 수집을 통해 농업 생산 활동의 가치를 극대화하는 것을 목표로 한다. 이것은 활용 가능하고, 시의 적절하며, 세부적인 정보가 포함되어 있는 데이터를 수집·분석·해석하는 방법을 의미한다. Global Development Lab의 iDesign팀이 DataDriven Farming Prize를 통해 네팔에서 농업 데이터를 활용한 사례가 있다.

\section{4) ICT 기술을 활용한 농업지도(ICT-enabled extension)}

디지털 채널(SMS, 라디오, 비디오 등)을 통해 농업기술 정보를 제공하는 것을 의미한다. 농업기술지도사(extension workers)는 농민을 포함한 가치사슬 단계별 이해관계자들에게 적 당한 시기에 그들이 필요한 정보를 제공함으로써 행동 변화를 돕는 역할을 하는데, 이때 커뮤니 케이션 채널을 디지털 기술로 보완하는 방식이다.

<표 3>은 Feed the Future에서 추진하고 있는 '농업 가치사슬의 디지털화(Digitalizing the agricultural value chain)'에 대한 설명이다. 시장 시스템이 통합적으로 발전할 수 있도록, 디지털 도구를 활용해 농업 가치사슬을 단계별로 연결할 수 있도록 지원하는 프로그램이다. 각 가치사슬에서 단계별 디지털화의 목적과 이를 달성하기 위한 데이터 수집, 금융 거래 방식, 사업의 사례를 소개하고 있다. 
〈표 3〉 농업 가치시슬 단계별 디지털화의 목적과 프로젝트 적용 요소 및 시례

\begin{tabular}{|c|c|c|c|c|}
\hline \multirow{2}{*}{$\begin{array}{l}\text { 가치사슬 } \\
\text { 단계 }\end{array}$} & \multirow{2}{*}{ 디지털화의 목적 } & \multicolumn{2}{|c|}{ 프로젝트 활동 요소 } & \multirow{2}{*}{ 사례7) } \\
\hline & & 데이터 수집 & 금융거래 & \\
\hline 계획 & $\begin{array}{l}\text { - 소농 대상으로 재배 대상 작물을 } \\
\text { 선정해 지원, 비즈니스 계획 수립 } \\
\text { 을 위한 데이터 제공 } \\
\text { - 바이어, 가공업자와 관계 강화 } \\
\text { - 기후변화 적응 }\end{array}$ & $\begin{array}{l}\text { - 농장지도(mapping) } \\
\text { - 기후변화 예측 모델 }\end{array}$ & $\begin{array}{l}\text { - 저축 } \\
\text { - 기초 신용 } \\
\text { - 보험 }\end{array}$ & $\begin{array}{l}\text { FarmBook, mFarm, } \\
\text { Cocoa Link, iCow }\end{array}$ \\
\hline 투입 & $\begin{array}{l}\text { - 위험 및 비용 감소 } \\
\text { - 투입재 품질 제고 } \\
\text { - 사전 수요조사 } \\
\text { - 구매, 저축, 신용 등의 정보 제공 } \\
\text { 편의 }\end{array}$ & $\begin{array}{l}\text { - 종자 · 비료 · 농약 } \\
\text { - 등급화 서비스 품질 } \\
\text { - 토양 · 수질 테스트 }\end{array}$ & $\begin{array}{l}\text { - 지불 } \\
\text { - 보조금 } \\
\text { - 저축, 거래 예약 - } \\
\text { 계획 } \\
\text { - 기초 신용 } \\
\text { - 임대차계약 }\end{array}$ & $\begin{array}{l}\text { MyAgro, Yelp for } \\
\text { Cows, GES } \\
\text { eVouchers Nigeria }\end{array}$ \\
\hline 생산 & $\begin{array}{l}\text { - 농업기술지도 서비스 확대 } \\
\text { - 재배 단계별 정보 알림 } \\
\text { - 영농 성공 사례의 확대를 통한 행 } \\
\text { 동 변화 } \\
\text { - 재배 작물 선택, 영농 기술 예 } \\
\text { 측-도입 확대 }\end{array}$ & $\begin{array}{l}\text { - 비료 · 농약 · 제초 } \\
\text { - 토양 · 관개 } \\
\text { - 농기계 및 서비스 } \\
\text { - 기상 }\end{array}$ & $\begin{array}{l}\text { - 지불(백신, 인증 } \\
\text { 서비스) } \\
\text { - 임금 }\end{array}$ & $\begin{array}{l}\text { Farm Radio Intl, } \\
\text { Digital Green, Avaaj } \\
\text { Otalo, Health } \\
\text { Network Intl(HNI)'s } \\
\text { IVR service, Hello } \\
\text { Tractor (Nigeria), } \\
\text { Farmerline }\end{array}$ \\
\hline 저장 & $\begin{array}{l}\text { - 농민-가공업자 간 연계 강화 } \\
\text { - 수확 후 손실 감소를 위한 기술정 } \\
\text { 보 제공 } \\
\text { - 수확 관련 대출 및 저장고 이용 } \\
\text { 정보 제공 }\end{array}$ & $\begin{array}{l}\text { - 저장고 } \\
\text { - 병해충 } \\
\text { - 보관 }\end{array}$ & $\begin{array}{l}\text { - 저장고 이용- 인증 } \\
\text { 영수증 } \\
\text { - 추가 투입 } \\
\text { - 대출 }\end{array}$ & $\begin{array}{l}\text { One Acre Fund } \\
\text { harvest loans(East } \\
\text { Africa) }\end{array}$ \\
\hline $\begin{array}{l}\text { 수확 후 } \\
\text { 가공 }\end{array}$ & $\begin{array}{l}\text { - 시장 가격에 대한 농민의 협상력 } \\
\text { 강화 } \\
\text { - 공급망 최적화, 등급화를 위한 산 } \\
\text { 지 추적 }\end{array}$ & $\begin{array}{l}\text { - 재배 품종 - 품질 } \\
\text { - 재배 - 수확 시기 }\end{array}$ & $\begin{array}{l}\text { - 지불 } \\
\text { - 보험 지불금 }\end{array}$ & $\begin{array}{l}\text { Nataal } \\
\text { Mbay(Senegal) }\end{array}$ \\
\hline 유통 & $\begin{array}{l}\text { - 물류비용 감소 } \\
\text { - 운송 형태 선택지 확대, 정보 제 } \\
\text { 공 }\end{array}$ & $\begin{array}{l}\text { - 보관 } \\
\text { - 기후 제어 } \\
\text { - 수요에 기반한 운송 } \\
\text { 판매 서비스 }\end{array}$ & $\begin{array}{l}\text { - 운송료 } \\
\text { - 협동조합비 }\end{array}$ & $\begin{array}{l}\text { Loop } \\
\text { transport/selling } \\
\text { service (India, } \\
\text { Ethiopia) }\end{array}$ \\
\hline $\begin{array}{l}\text { 시장 } \\
\text { 접근 }\end{array}$ & $\begin{array}{l}\text { - 소농의 시장 접근성 강화(인증, } \\
\text { 산지 추적 등의 정보 제공) } \\
\text { - 시장 가격 정보 제공 }\end{array}$ & $\begin{array}{l}\text { - 판매 - 지불 } \\
\text { - 품질관리 } \\
\text { - 시장 가격 }\end{array}$ & $\begin{array}{l}\text { - 생산자-구매자 간 } \\
\text { 지불 } \\
\text { - 저축 } \\
\text { - 상품 구매 예약 }\end{array}$ & $\begin{array}{l}\text { Esoko market price } \\
\text { service (Ghana), } \\
\text { FreshPro(Kenya) }\end{array}$ \\
\hline
\end{tabular}

출처: USAID (2018)2. USAID의 모바일 농업 민관 파트너십 사업 사례

7) 각 사례는 지면 관계상 생략. 구체적 정보는 USAID 웹사이트 참조(저자 주). 


\section{USAID의 모바일 농업 민관 파트너십 사업 시례}

USAID가 Feed the Future의 주요 협력 대상 국가인 케냐, 모잠비크, 탄자니아에서 농민의 빈곤 극복과 회복력 증진을 목표로 추진한 민관 파트너십사업인 The Connected Farmer Alliance(이하 CFA) 프로젝트를 소개한다.

CFA는 통신회사인 Vodafone, 농업 분야 NGO인 TechnoServe와 함께 2012년부터 2016 년까지 모바일 솔루션을 기반으로 공급망의 효율성 제고, 농민의 접근성 개선, 금융 서비스 제공 등을 목표로 총 사업비 10,100,320 달러가 소요되었다. 수혜자인 소농 50만 명의 생산성 및 소득 증대, 농산업 수입 증대를 목표로 했다.

케냐, 모잠비크, 탄자니아에서는 농업 부문의 고용이 75 80\%를 차지하고 있다. 그런데도 전체 소득은 $20 \%$ 내외만 차지하고 있으며, 농민의 대다수는 1 ha 미만의 토지를 소유하고 있는 상황이다. 흩어져 살고 있는 농민들은 직접적인 현금 거래가 어렵고, 공급망에서 필요한 정보(거래, 유통, 시장 가격 정보)에 대한 접근이 어렵다. 또한 그 과정에서 오가는 정보의 투명성도 보장하기 어려운 상황이다. 이러한 문제는 통신 업체인 Vodafone의 M-Pesa8)의 모바일 솔루션을 통해 간편 결제, 정보 및 농업 기자재 제공을 통한 농민의 충성도 제고, 농업기 술 정보 제공(생산량, 병해충) 등으로 해결하고자 한 것이 동 프로젝트의 주요 목적이다. 동 사업은 첫째, 농업 비즈니스(agribusiness) 증진을 위해 B2B 공급사슬 방식의 솔루션을 개발 한다. 둘째, 단순 결제와 송금 방식을 넘어서 농민의 자산 축적, 생산성 강화, 재무적 위험성 감소를 위한 금융 서비스 개발을 목표로 한다.

직접적인 계좌 개설이 어렵고, 신용도가 낮아 금융 접근성이 낮은 농민은 모바일을 통해 현금을 쉽게 주고받을 수 있으며, 농업 가치사슬의 전반에 걸쳐 필요한 정보들을 쌍방향 커뮤니 케이션을 통해 주고받는다. 이 과정에서 농업 비즈니스 활동이 이루어지게 되고, 농업 비즈니스 -모바일 업체, 농업 비즈니스-농민 간 주고받는 서비스에 대한 비용이 발생하게 된다(<그림 2>). 사업 추진 과정에서 TechnoServe는 농업기술, 모바일 솔루션 활용과 같은 농민 훈련, 기술교 육 등을 담당했다.

농산물의 생산 과정에서 산출되는 데이터(작물 생산량, 시비량 등)는 농민이 입력을 하고, 필요로 하는 정보(품종 선택, 재배 기술, 병해충, 농기계, 기상, 비료, 시장 가격 등)는 SMS 혹은 헬프데스크를 통해 일방 - 쌍방향 커뮤니케이션으로 제공된다. 이렇게 모아진 데이터를

8) M-Pesa : 케냐의 통신사 Safari Com.과 남아프리카 공화국의 통신사 Vodacom의 모바일을 이용한 비접촉식 결제, 송금, 소액 금융 등을 제공하는 서비스로서 자세한 사항은 M-Pesa 웹사이트 참조(저자 주). 
활용하는 주체는 농업 비즈니스 섹터지만, $\mathrm{CFA}$ 에 참여하는 농민들은 이들과 별개의 주체가 아니라 참여자의 하나로 데이터를 활용하는 주체가 되기도 한다.

〈그림 2〉 The Connected Farmer Alliance의 Business-to-Business-to-Customer(B2B2C) 모델

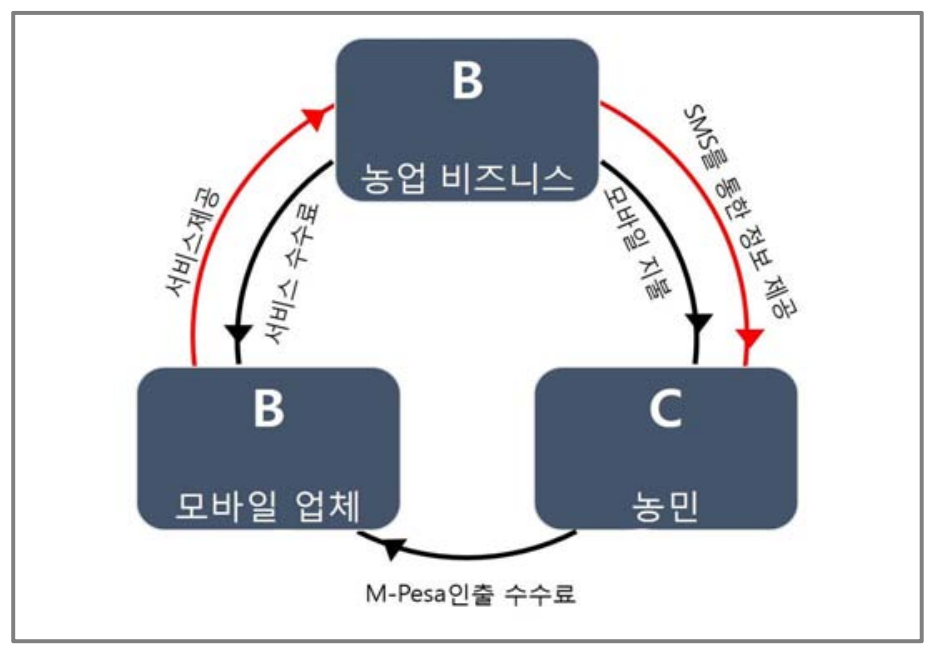

출처: TechnoServe (2016)에서 재인용

<그림 3>은 농민이 CFA에 참여하는 과정을 나타낸다. 참여 농민으로 등록하고, 투입재(종 자, 농기계 등)를 지원받아 생산 활동을 시작하면, 이후 재배 단계별로 훈련 및 현장보고 등의 과정을 거쳐 사업에 참여하게 된다.

〈그림 3〉 USAID의 The Connected Farmers Alliance의 농민 참여 모식도

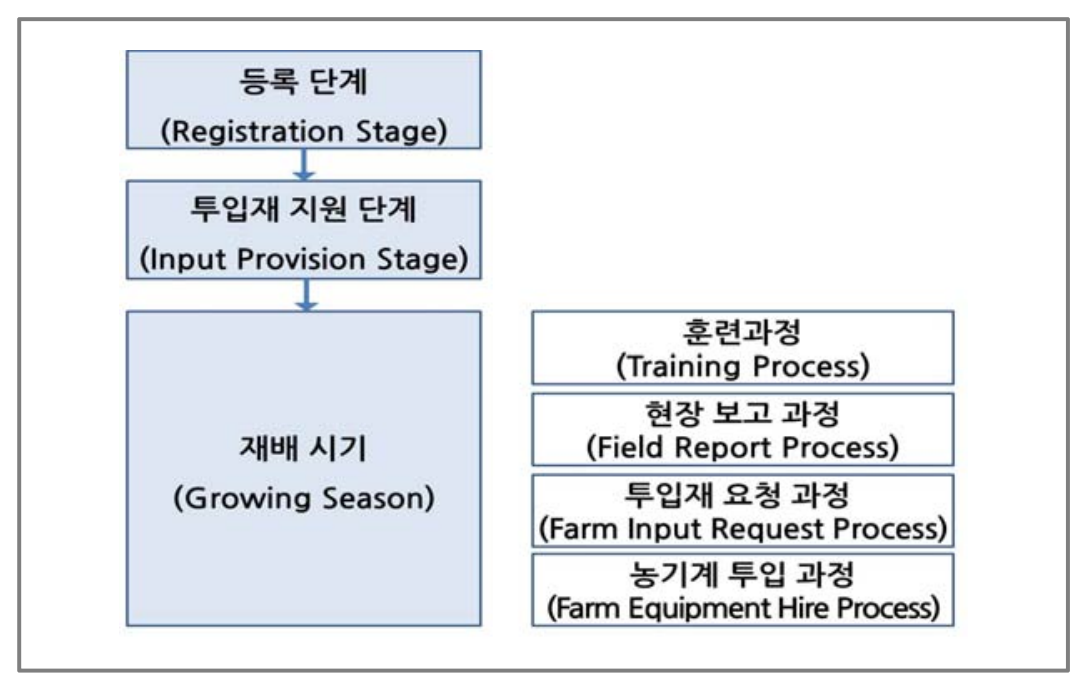

출처: USAID (2018) 
이 과정에서 각 단계별 솔루션이 <표 4>와 같이 제공된다.

〈표 4〉 USAID의 The Connected Farmers Alliance 사업 내용 및 지원 시스템

\begin{tabular}{|c|c|c|}
\hline \multicolumn{2}{|r|}{ 모바일을 활용한 공급사슬 } & CFA시스템 \\
\hline 농민 정보 & 정확한 정보의 생산 및 수집 & 농민등록시스템 \\
\hline 대출 지원 & 적합한 시기와 정확한 금액의 대출 지원 & 대출상환시스템 \\
\hline 대금 결제 & 적합한 시기의 결제 & 결제· 영수시스템 \\
\hline 커뮤니케이션 & 농민에게 저렴하고 빠른 소통 채널 제공 & 정보알림시스템 \\
\hline 물류 & 수거, 배송 시간 관리 및 추적 & 물류·추적시스템 \\
\hline 피드백 & 재배 시기별 농민의 피드백 전달 & 현황리포트시스템 \\
\hline
\end{tabular}

출처: USAID (2018) 


\section{IV. 결론 및 시사점}

\section{1. 농업 가치시슬을 확대하기 위한 디지털 기술의 적용}

개발도상국의 국가경제 발전과 SDGs를 달성하기 위해 농업의 발전은 필수적이다. 특히 농작물의 재배 과정을 비롯해 수확, 저장, 가공, 유통, 판매에 이르는 가치사슬의 단계에서 그동 안 수혜 대상자로만 여겨졌던 소농이 참여자로 인식되고, 직간접적으로 참여함으로써 지속 가능한 식량생산시스템을 구축하는 것이 최근 국제개발협력 프로젝트의 지향점이다.

GSMA(2018)에 의하면, 2017년 현재 전 세계 인구 중 50억 명이 모바일 서비스를 받고 있으며, 2025년까지 전 세계 인구의 $71 \%$ 가 이 서비스를 받을 수 있도록 하는 것을 목표로 하고 있다. 이러한 모바일 서비스의 확대는 농업 분야의 SDGs 달성에 매우 중요한 역할을 한다. 농촌 지역에 거주하는 농민의 생산 활동에 필요한 농업기술, 재정적인 지원(금융 접근성), 제도적인 지원 등이 더해져 가치사슬이 확대되는 과정에서 디지털 기술을 활용함으로써 정보의 접근성, 투명성, 효율성 등을 높일 수 있다.

\section{KOICA의 사업 시례와 향후 적용을 위한 시사점}

앞서 살펴본 USAID의 사업 사례를 한국국제협력단(Korea International Cooperation Agency, 이하 KOICA)의 사업에 적용시키기 위한 방안을 모색해 보고자 한다.

$\mathrm{KOICA}$ 는 국내 통신 업체인 $\mathrm{KT}$ 와 함께 방글라데시에서 지속 가능한 농업 비즈니스를 추진 하고 있다. 이를 통해 지역 주민의 소득 증대를 목표로, '방글라데시 전자상거래를 통한 농업 비즈니스 기회창출사업(2017 2019)'을 수행하고 있다. 아울러 국제이주기구(International Organization for Migration, $\mathrm{IOM}$ ), 전자상거래 관련 NGO인 ADAG(Amar Desh Amar Gram, 전자상거래 업체), 콕스바자르 지방정부, 모헤시칼리 지방정부와 공동 수행하고 있으며, 총 사업비는 12 억 원이다.

사업 대상지인 방글라데시 남동부 콕스바자르(Cox‘s Bazar) 지역의 모헤시칼리(Moheshkhali) 섬은 약 $362.18 \mathrm{~km}^{2}$ 의 면적에 30 만 여명이 거주하는 지역으로, 수도인 다카에서 약 $400 \mathrm{~km}$ 가량 떨어진 곳이다. 전체 인구의 약 $40 \%$ 가 빈곤선 아래에 살고 있으며, $62 \%$ 가 농업에 종사하고 있다. 하지만 기후변화로 인한 해수면 상승과 침수, 이로 인한 토양의 염분화가 가속되고 있어 농업 생산 활동에 많은 어려움을 겪고 있는 상황이다. 
방글라데시 정부는 소외 지역 주민들의 정보 접근성 개선을 통한 도농 간 발전 격차를 감소시 키기 위해 정보통신기술(Information and Communications Technologies, 이하 ICT)을 활용한 'Digital Vision 2021' 전략을 수립했다. 또한 농업부에서는 농업기술(통합적 병해충 관리 포함) 정보 제공을 위한 센터를 설립해 서비스를 제공하고는 있지만, 모헤시칼리의 경우에 는 지리적으로 고립된 환경과 불안정한 전기 공급 및 인터넷 연결 등으로 거의 사용되고 있지 않는 상황이다. 이렇듯, 열악한 상황을 ICT로 극복하고자 하는 것이 동 사업의 주요 목표다.

「KOICA 농촌개발 중기전략(2016 2020),의 전략 목표 중 하나는 '지속 가능한 농업 생산 증대 및 시장성 강화'다. 이행 프로그램으로, 농업의 시장성 강화를 위한 다양한 프로그램(수확 후 관리, 농업 가치사슬 확대)이 추진되고 있다. 기초선조사 결과 주요 생산물(잎담배, 소금, 생선)에 대한 수요를 조사했으며, 이들의 생계를 지속적으로 향상시키기 위해 생산-판매 채널을 구축하고, 이 과정에 필요한 기술적 지원책으로 ICT를 활용한 것이다. 아울러 원격 교육을 통해 농업생산기술을 지도하고, 판매 정보 및 유통 채널을 구축해 시장 접근성을 높이는 활동을 하게 된다.

동 사업은 현재 진행 중이므로 사업의 성과에 대해 언급할 수 있는 단계는 아니지만, 향후 우리나라 농업 분야 사업에 적용할 수 있는 요소를 충분히 반영하고 있다. 또한 타 분야(ICT, 보건, 영양, 교육)와 통합적인 관점에서 접근하는 방식을 검토해 볼 필요가 있다. 


\section{참고 문헌}

김동훈·허장. 2016. “농업분야 국제개발협력의 연구동향과 함의." 『한국국제농업개발학

회지』. 28(4):435-442.

김수진·이효정·오수현. 2016. 『 $\mathrm{KOICA}$ 농업분야 $\mathrm{CSV}$ 사업기획을 위한 가치사슬분석법

(Value Chain Analysis) 적용방안』. 성남: 한국국제협력단.

김연중·박기환·서대석·한혜성. 2010. 『주요 농산물의 가치사슬 분석과 성과제고 방안,

한국농촌경제연구원 연구보고서』. 한국농촌경제연구원.

이상급. 2018. "Data, Digital and Development: 4차 산업혁명 패러다임에 따른 주요

원조기관들의 대응 동향." 『국제개발협력』 2018년 제2호:43-63.

이효정. 2014a. “ICT를 활용한 농업부문 국제개발협력." 『세계농업』 제170호: 137-149. . 2014b. “미국의 농업부문 ODA 현황과 사례.”『세계농업』제166호: 43-66. . 2018. "개발도상국 식량시스템의 전환을 위한 농업의 혁신, 과학 기술에서 시작한다."

${ }^{『} \mathrm{KOICA}$ 이슈리포트』2018년 6호. 성남: 한국국제협력단.

이효정 - 지성태. 2016. “농림수산.” 『국제개발협력-심화 편』. KOICA ODA 교육원 역.

성남: 한국국제협력단: 183-253.

Africa Growth Initiative. 2018. "Foresight Africa: Top priorities for the continent in 2018." Washington, D.C.: The Brookings Institution.

FAO. 2013. "ICT uses for inclusive agricultural value chain.” Rome: Food and Agriculture of the United Nations (FAO).

IFAD. 2014. "How to do: Commodity value chain development projects." Rome: International Fund for Agricultural Development (IFAD).

IFAD. 2016. "How to do: Public-Private-Producer-Partnership (4Ps) in agricultural value chains." Rome: International Fund for Agricultural Development (IFAD).

GSMA. 2017. "Opportunities in agricultural value chain digitisation: Learning from Uganda." London: GSM Association (GSMA).

OXFAM, Vodafone, and Accenture. 2011. "Connected Agriculture: The role of mobile in driving efficiency and sustainability in the food and agriculture value chain." Oxford: OXFAM.

UNIDO. 2011. "Diagnostics for industrial value chain development: An integrated 
tool." Vienna: United Nations Industrial Development Organization (UNIDO). USAID. 2018. "Digital tools in USAID agricultural programming toolkit." Washington D.C.: United States Agency for International Development (USAID).

World Bank. 2017. "Atlas of Sustainable Development Goals 2017: From World Development Indicators, Washington.” Washington D.C.: World Bank.

WEF. 2018. "Innovation with a Purpose: The role of technology innovation in accelerating food systems transformation." Geneva: World Economic Forum (WEF).

$\mathrm{USAID}$ (미국국제개발처)의 'Feed the Future' 이니셔티브 홈페이지: https://www. usaid.gov/what-we-do/agriculture-and-food-security/increasing-food-se curity-through-feed-future (접속일: 2018.08.01.).

통신업체 Vodafone의 M-Pesa 서비스 소개 홈페이지:

https://www.mpesa.in/portal/ (접속일: 2018.08.01.). 